Wojciech RYCZEK*

\title{
UT FIGURA SIT. BEDA CZCIGODNY O TROPACH PISMA ${ }^{* *}$
}

Interpretacja ksiąg biblijnych oznacza często interpretację kluczowych dla nich tropów i figur. Wiedzieli o tym znakomicie wykształceni retorycznie Ojcowie Kościoła ze św. Grzegorzem z Nazjanzu, św. Hieronimem, św. Augustynem i św. Grzegorzem Wielkim na czele. W zaproponowanym modelu egzegezy poświęcali na ogół niewiele miejsca rozważaniom nad konkretnymi formami ze słownika antycznej teorii wymowy. Od nazywania i opisywania form wysłowienia, przykładowo metafory, metonimii czy alegorii, woleli ujawniać ukrywające się za nimi znaczenia. Wszelkie wieloznaczne i zmuszające do podjęcia trudu interpretacji wyrażenia nazywali ogólnie figurami. Nieco inaczej postapił Beda Czcigodny ( $† 735)$, niekiedy uznawany za autora, który zamyka okres patrystyczny i otwiera wczesne średniowiecze, prezbiter i benedyktyn związany z klasztorami w Wearmouth i Jarrow w Nortumbrii, twórca traktatu o tropach i figurach Pisma, wielokrotnie kopiowanego w ,wiekach średnich" i często drukowanego w czasach nowożytnych.

Dwa niewielkie dzieła Bedy - O figurach i tropach (De schematibus et tropis $^{1}$ i $O$ sztuce metrycznej (De arte metrica) - powstały w tym samym czasie (ok. 710) ${ }^{2}$ i zostały dedykowane jego uczniowi, diakonowi o imieniu Cuthbert. Definicje i niektóre przykłady form retorycznych zaczerpnął autor

${ }^{*}$ Dr Wojciech Ryczek - pracownik Katedry Historii Literatury Staropolskiej na Wydziale Polonistyki Uniwersytetu Jagiellońskiegow Krakowie; e-mail: wojtek.ryczek@interia.pl.

** Publikacja powstała w ramach grantu naukowego Politropia: wczesnonowożytne teorie i koncepcje figuratywności, finansowanego ze środków Narodowego Centrum Nauki przyznanych na podstawie decyzji numer DEC-2013/11/D/HS2/04529.

${ }^{1}$ Por. J.P. Elder, Did Remigius of Auxerre Comment on Bede's De schematibus et tropis?, „Mediaeval Studies” 9 (1947) 141-150; J.J. Murphy, Rhetoric in the Middle Ages. A History of Rhetorical Theory from Saint Augustine to the Renaissance, Berkeley - Los Angeles 1974, 77-80; G.H. Brown, Bede The Venerable, Boston 1987, 33-36; P.H. Blair, The World of Bede, Cambridge (MA) 1990, 249-250; R. Copeland, Rhetoric, Hermeneutics and Translation in the Middle Ages. Academic Traditions and Vernacular Texts, Cambridge 1991, 58-60; G. Knappe, Traditionen der klassischen Rhetorik im angelsächsischen England, Heidelberg 1996, 239-240; R.L. Ray, Bede, Rhetoric, and the Creation of Christian Latin Culture, Jarrow 1997, passim; A. Thacker, Bede and Augustine of Hippo. History and Figure in Sacred Text, Jarrow 2005, passim.

${ }^{2}$ Por. C.V. Franklin, The Date of Composition of Bede's „,De schematibus et tropis” and „De arte metrica", RBen 110 (2000) 199-203. 
w niezmienionej postaci z trzeciej księgi podręcznika gramatyki Donata Ars maior. Jak wykazał Ulrich Schindel, Beda korzystał prawdopodobnie również ze ,schrystianizowanej” wersji tego traktatu, uzupełnionej licznymi przykładami figur z Pisma Świętego, a znanej wcześniej św. Izydorowi z Sewilli i Julianowi z Toledo ${ }^{3}$. Oprócz cytatów z autorów antycznych (Enniusza cytowanego za pośrednictwem gramatyka Diomedesa, Terencjusza, Plauta i Wergiliusza) znajdziemy w jego dziele także ślady lektury Kasjodora (Komentarz do Księgi Psalmów) $)^{4}$, św. Augustyna (O nauce chrześcijańskiej, Objaśnienia Psalmów) i św. Grzegorza (Moralia, obszerny, alegoryczny wykład Księgi Hioba $)^{5}$. Przedstawienie nauki o tropach, wyłożonej w zwięzły i przystępny sposób przez Bedę, pozwoli pokazać w moim przekonaniu przenikanie gramatyczno-retorycznej nauki o figurach do wczesnośredniowiecznej egzegezy biblijnej.

Martin Irvine zwrócił uwagę, że podręcznik angielskiego benedyktyna uznawany jest często przez badaczy wymowy za traktat retoryczny ${ }^{6}$. Wyrasta on jednak z tradycji gramatycznej, a konkretnie z objaśniania autorów (enarratio), które obok rozwijania kompetencji językowej (scientia loquendi) stanowiło integralną część ówczesnego nauczania tej sztuki ${ }^{7}$. Nie przypadkiem definicje, podziały i niektóre przykłady tropów i figur przejął Beda w niezmienionej postaci od Donata. W miejsce cieszących się uznaniem z powodu czystości i językowego wyrafinowania poetów (auctores) wprowadził autorów ksiąg biblijnych, odznaczających się najwyższą powagą (auctoritas). Reguły ich objaśniania pozostały jednak niezmienne. Można powiedzieć, że w dziele Bedy krzyżują się dwie bliskie sobie tradycje: gramatyczna - związana z odkształceniem formy i znaczenia wyrażeń językowych względem normy poprawności i retoryczna - oscylująca wokół troski o ozdobność wysłowienia i piękno mowy ${ }^{8}$. W centrum ich uwagi znajduje się nie tylko znaczone (rzeczy oznaczane), ale także znaczące (sposoby oznaczania). O hermeneutycznej orientacji podręcznika Bedy świadczy najlepiej rozbudowanie sekcji poświęconej alegorii i jej licznym odmianom, głównie figurom ironii, np. antyfrazie, asteizmowi czy sarkazmowi. Od zwięzłych definicji Donata przechodzi

\footnotetext{
${ }^{3}$ Por. U. Schindel, Die Quellen von Bedas Figurenlehre, CM 29 (1968) 169-186.

${ }^{4}$ Por. K. Burczak, Figury retoryczne i tropy w Psalmach na podstawie ,Expositio Psalmorum” Kasjodora, Lublin 2004, 67-68 (o podręczniku Bedy).

${ }^{5}$ Por. S. DeGregorio, The Venerable Bede and Gregory the Great: Exegetical Connections, Spiritual Departures, „Early Medieval Europe” 18 (2010) 43-60.

${ }^{6}$ Por. M. Irvine, The Making of Textual Culture: 'Grammatica' and Literary Theory 350-1100, Cambridge (MA) 1994, 293.

${ }^{7}$ Por. L.D. Green, Grammatica movet: Renaissance Grammar Books and elocutio, w: Rhetorica movet. Studies in Historical and Modern Rhetoric in Honour of Heinrich F. Plett, ed. P.L. Oesterreich - T.O. Sloane, Leiden 1999, 73-115; S. Reynolds, Medieval Reading. Grammar, Rhetoric and the Classical Text, Cambridge 2004, 21-28; T. Michałowska, Średniowieczna teoria literatury w Polsce. Rekonesans, Torun 2016, 47 i 136.

${ }^{8}$ Por. T. Michałowska, Literatura polskiego średniowiecza wobec poetyki europejskiej (,,ornatus difficilis"), Warszawa 2008, 46-65.
} 
bowiem autor do wykładu nauki o poczwórnym znaczeniu tekstu Pisma, opatrzonej konkretnymi przykładami.

Dzieło angielskiego uczonego ukazało się po raz pierwszy drukiem w 1473 r. w Mediolanie pod tytułem De schematibus et tropis sacrae Scripturae (O figurach i tropach Pisma Świętego $)^{9}$. Było następnie wielokrotnie przedrukowywane, stanowiąc niekiedy suplement do innego traktatu retorycznego, np. podręcznika Piotra Schadego, zwanego Mosellanusem, Tabulae de schematibus et tropis (Tablice przedstawiajace tropy i figury), Bazylea 1541, albo zbioru rozpraw takich retorów łacińskich jak: Aquila Romanus, Juliusz Rufinianus, Publiusz Rutiliusz Lupus, Alkuin, Kasjodor, Izydor z Sewilli, Martianus Capella (Antiqui rhetores Latini, Paryż 1599). Dzieło Bedy uzupełniało wiedzę o retoryce przykładami tropów oraz figur z Pisma i stanowiło wykład hermeneutyki biblijnej, niezbędnej w opanowaniu reguł sztuki kaznodziejskiej. Ukazując retoryczne piękno świętych ksiąg, oddawało - jak powiada M. Irvine - „Pismu to, co należy do Pisma”"

1. Figuratywność Pisma. W przedmowie do ucznia i czytelników swego dzieła zwraca Beda uwagę na występowanie rozmaitych figur retorycznych w tekście biblijnym:

„Zwykło się znajdować niekiedy w Piśmie figuratywny porządek słów z powodu ozdobności, inny niż występujący w zwykłym mówieniu. Gramatycy określają go po grecku schematem, my nazywamy go odpowiednio zwyczajem, formą albo figura, gdyż dzięki niemu odkształca się w pewien sposób i ozdabia mowę. Zwykło się również znajdować wypowiedź tropiczną, która powstaje dzięki wyrażeniu przeniesionemu $\mathrm{z}$ właściwego znaczenia na niewłaściwe, lecz podobne [znaczenie] z powodu konieczności albo ozdobności. Grecy przechwalają się, że byli wynalazcami tych tropów i figur. Lecz przekonasz się, najdroższy synu, i przekonają się wszyscy, którzy zechcą przeczytać to dziełko, że Pismo Święte przewyższa wszystkie inne dzieła nie tylko autorytetem (gdyż jest boski) czy użytecznością (gdyż prowadzi do życia wiecznego), lecz także starożytnością i samą wymową. Postanowiłem wykazać to na podstawie zebranych przykładów z Pisma, ponieważ nauczyciele jakiejś świeckiej wymowy nie mogą przedstawić żadnego z tych schematów czy tropów, który nie pojawiłby się wcześniej w Piśmie"11.

${ }^{9}$ Por. L.D. Green - J.J. Murphy, Renaissance Rhetoric Short Title Catalogue: 1460-1700, Aldershot 2006, 27, 65 i 392.

${ }^{10}$ Irvine, The Making of Textual Culture, s. 293.

${ }^{11}$ Beda Presbyter Anglosaxonis, De schematibus et tropis sacrarum litterarum liber, Basileae: apud Adamum Petrum, mense Augusto 1527, A2: „Solet aliquoties in Scripturis ordo verborum causa decoris aliter quam vulgaris via dicendi habet figuratus inveniri, quod grammatici Graece schema vocant, nos habitum, vel formam, vel figuram recte nominamus, quia per hoc quodammodo vertitur et ornatur oratio. Solet iterum tropica locutio reperiri, quae fit translata dictione a propria significatione ad non propriam similitudinem, necessitatis aut ornatus gratia. Equidem gloriantur 
Angielski prezbiter mówi jednym głosem z tymi autorami chrześcijańskimi (św. Augustyn, św. Hieronim, Kasjodor, Izydor z Sewilli), którzy podkreślali retoryczną organizację tekstu Pisma. Nie przeciwstawiali oni ksiąg natchnionych dziełom autorów pogańskich, zwłaszcza Platona, Demostenesa, Cycerona i Wergiliusza, ale często powtarzali, że w niczym im one nie ustępuja, a pod wieloma względami (autorytet, użyteczność, starożytność, wymowa) znacznie je przewyższają. Jeśli nawet Grecy opracowali teorię elokucji w postaci katalogu tropów i figur retorycznych, różnorodne formy wysłowienia występowały już wcześniej, np. w starotestamentowych narracjach czy mowach proroków. Odnajdujemy w nich realizacje rozmaitych schematów językowych, skrupulatnie opisywanych i porządkowanych przez antycznych retorów. Argument Bedy dowodzi pośrednio oprócz figuratywności Pisma również tezy o uniwersalności tropów i figur, obecnych w ludzkim języku nawet bez konieczności ich nazywania.

Kwestia ozdobności retorycznej (ornatus) odgrywała dużą rolę w sztuce homiletyki opracowanej przez św. Augustyna, w której centrum znalazła się hermeneutyka biblijna. Kaznodzieja powinien wyjaśniać słowa Pisma nie tylko mądrze, ale także pięknie i ozdobnie. Podkreślając wielokrotnie ścisły związek między mądrością a wymową, afrykański biskup przestrzegał swoich uczniów przed sprowadzaniem retoryki wyłącznie do kompetencji elokucyjnej, czyli umiejętności operowania wyszukanymi tropami i figurami:

„Gdy to osiagną, z rozkoszą sycą się samą prawdą. Cechą bowiem umysłów wybitnych jest miłość prawdy w słowach, a nie miłość samych słów. Bo i na co zda się nawet złoty klucz, jeśli nim nie można otworzyć tego, co otworzyć pragniemy? I co przeszkadza, że klucz jest drewniany, skoro jest przydatny, my zaś niczego innego nie pragniemy jak otwarcia tego, co zamknięte. Ponieważ więc zachodzi pewne podobieństwo między posilającymi się a uczącymi się, należy dla uniknięcia niesmaku w większości przypadków przyprawiać potrawy, nawet te, bez których człowiek nie potrafi żyć"12.

Graeci talium se figurarum vel troporum fuisse repertores. Sed ut cognoscas, dilectissimi fili, cognascant item omnes, qui haec legere voluerint, quod sancta Scriptura caeteris omnibus scripturis non solum auctoritate, quia divina est, vel utilitate, quia ad vitam ducit aeternam, sed et antiquitate et ipsa praeminet positione dicendi. Placuit mihi collectis de ipsa exemplis ostendere, quia nihil huius modi schematum, sive troporum valent praetendere ullis saeculis eloquentiae magistri, quam non illa praecesserit". Tekst zamieszczony w PL 90, 175-186 pozbawiono przykładów z literatury antycznej. W dwóch miejscach (oznaczonych w tekście*) wprowadziłem bardziej prawdopodobne moim zdaniem lekcje występujące $\mathrm{w}$ innych przekazach tekstu. Wszystkie przekłady, o ile nie zaznaczono inaczej, pochodzą ode mnie.

${ }^{12}$ Augustinus, De doctrina christiana IV 11, 26, PL 34, 100-101, tłum. J. Sulowski: Św. Augustyn, O nauce chrześcijańskiej, Warszawa 1989, 210-211: „Quod cum adepti fuerint, ipsa delectabiliter veritate pascuntur, bonorumque ingeniorum insignis est indoles in verbis verum amare, non verba. Quid enim prodest clavis aurea, si aperire, quod volumus, non potest? Aut quid obest lignea, si hoc potest? Quando nihil quaerimus nisi patere, quod clausum est. Sed quoniam inter se habent 
Mierzona miarą znajomością Pisma i nauki chrześcijańskiej mądrość zakłada zdolność wysłowienia. Dzięki artykulacji językowej można najlepiej ujawnić swe myśli i przeżycia. Wymowa stanowi integralną część mądrości, a mądrość obejmuje z konieczności wymowę. $\mathrm{Z}$ tego powodu zachodzące między nimi relacje opisuje mechanizm wzajemnego warunkowania i uzupełniania. Św. Augustyn sięga w ich opisie po sugestywne personifikacje: „mądrość wychodzi ze swego domu, to znaczy serca mędrca, za nią zaś podąża wymowa niczym nieodłączna służąca, nawet niewołana"13. Okazuje się tym samym, że tylko mędrzec zasługuje na miano prawdziwego mówcy. Znajomość retoryki jest u niego w dodatku pochodną zdobytej wcześniej mądrości ${ }^{14}$.

Aby wyjaśnić znaczenie ozdobności (szerzej: retoryki opisywanej przez pryzmat elokucji) w interpretacji Pisma, św. Augustyn posługuje się obrazową alegorią o dwóch kluczach, złotym i drewnianym. Wyobrażają one figuratywnie (metaforycznie) dwa sposoby czytania i komentowania ksiag biblijnych. Pierwszy z nich koncentruje się wokół dopracowanych retorycznie form wysłowienia, drugi czyni swoim znakiem rozpoznawczym językową zwięzłość i prostotę. Pierwszy obfituje w tropy i figury, drugi - w zwykłe i niewyszukane wyrażenia językowe. Zasadnicza różnica między nimi zaznacza się wyraźnie w ich interpretacyjnej użyteczności. Drewniany klucz, czytelna metafora prostego stylu i ozdobności ograniczonej do niezbędnego minimum, potrafi otworzyć biblijne fragmenty na nowe odczytania. Przykładu takiej lektury retorycznej dostarczył sam autor, analizując i omawiając klimaks (gradatio) w jednym z listów św. Pawła (Rz 5, 3-5) $)^{15}$. Tworząc zasady wyjaśniania figur Pisma, św. Augustyn jako mędrzec i retor korzysta z różnych form retorycznych nawet w podręczniku homiletyki. Dlatego o tropach i figurach mówi za pomocą obrazowej alegorii dwóch kluczy. Zachęcając przy tym swoich uczniów do sięgania po drewniany klucz, sam wybiera ten złoty.

2. Biblijne tropy. W omówieniu pojęcia tropu i jego odmian korzysta Beda z definicji zaproponowanych przez Donata i przyjętych przez wielu późniejszych retorów:

„Trop jest wyrażeniem przeniesionym z właściwego znaczenia na niewłaściwe, lecz podobne [znaczenie] z powodu ozdobności albo konieczności. Tropy

\footnotetext{
nonullam similitudinem vescentes atque discentes, propter fastidia plurimorum, etiam ipsa sine quibus vivi non potest alimenta condienda sunt".

${ }^{13}$ Tamże IV 6, 10, PL 34, 93: ,[...] quasi sapientiam de domo sua, id est pectore sapientis procedere intellegas et tamquam inseparabilem famulam etiam non vocatam sequi eloquentia", thum. Sulowski, s. 190-191.

${ }^{14}$ Por. W. Ryczek, ,De rhetorica christiana” św. Augustyna: między filologiq a filozofia, w: Studia rhetorica, red. M. Choptiany - W. Ryczek, Kraków 2011, 215-216.

${ }^{15}$ Por. Augustinus, De doctrina christiana IV 7, 11.
} 
więc, które można nazwać po łacinie sposobami albo zwyczajami [mówienia], występują w liczbie trzynastu [...]"16.

Istotę zmiany językowej, motywowanej albo koniecznością nazywania (ograniczona liczba słów), albo ozdobnością (retoryczny postulat pięknego mówienia), zwanej tropem stanowi zatem przeniesienie znaczenia w obrębie podobnych do siebie rzeczy. Ogólnie sformułowana definicji umożliwia objęcie nią wielu różnych, niekiedy całkiem odmiennych strukturalnie, form wysłowienia. Beda wyróżnia, podążając wiernie za gramatyką Donata, trzynaście tropów: metafora, katachreza, metalepsa, metonimia, antonomazja, epitet, synekdocha, onomatopeja, peryfraza, hyperbaton, hiperbola, alegoria i homoiosis. Dodatkowo trzy z nich - hyperbaton, alegoria i homoiosis - przybiera różne postaci językowe.

Wyliczenie tropów rozpoczyna metafora, ujmowana zgodnie z tradycją gramatyczną ukształtowaną w dużej mierze przez Donata jako ,przeniesienie rzeczy i słów (rerum verborumque translatio)". Tę lapidarną, a nawet enigmatyczną definicję rozwija Beda za pomocą przywołania czterech sposobów tworzenia przenośni, opisanych w Ars maior ${ }^{17}$, z których każdy wskazuje kierunek translacji semantycznej, stanowiącej istotę tego tropu. Są one następujące: od czegoś ożywionego do czegoś ożywionego (ab animali ad animale), np.: „Pan, który wyrwał mnie z paszczy lwa i łapy niedźwiedzia” (1Sm 17, $37)^{18}$, „dlaczego narody szemrają?” (Ps 2, 1), ,gdybym przybrał skrzydła jutrzenki" (Ps 138, 9); od czegoś nieożywionego do czegoś nieożywionego (ab inanimali ad inanimale), np. ,otwórz twe bramy, Libanie” (Za 11, 1), ,wszystko, co szlaki mórz przemierza" (Ps 8, 9); od czegoś ożywionego do czegoś nieożywionego (ab animali ad inanimale), np.: „szczyt [dosł. vertex, czyli również czubek głowy] Karmelu uschnie" (Am 1, 2); i wreszcie od czegoś nieożywionego do czegoś ożywionego (ab inanimali ad animale), np.: „usunę z ich ciała serce kamienne" (Ez 11, 19). Kryterium podziału rzeczy, które biora udział w tej wymianie słów, stanowi posiadanie duszy.

Metafora może być zdaniem Bedy przechodnia (reciproca), zwana również antystrofą, czyli otwarta na odwrócenie kolejności tworzących ją wyrażeń, jak np. u Wergiliusza ,wiosło skrzydeł"19, gdyż mówimy o skrzydłach ptaków, jak i o wiosłach skrzydeł. Albo nieprzechodnia (partis unius), jak np. „falujące zasiewy”. Ten podział metafor powtórzył wiernie angielski benedyktyn za Donatem. Zwrócił on jednak uwagę, że przenośnie pojawiają się najczęściej ze wszystkich tropów w mówieniu o Bogu:

${ }^{16}$ Beda, De schematibus et tropis, A8: „Tropus est dictio translata a propria significatione ad

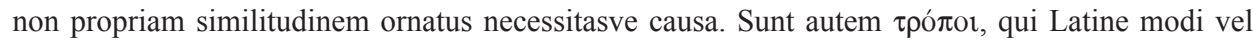
mores interpretari possunt, numero tredecim [...]".

${ }^{17}$ Por. Reynolds, Medieval Reading, s. 125-126.

${ }^{18}$ Korzystam z przekładu Biblii Tysiąclecia; często wprowadzam jednak zmiany (od drobnego retuszu językowego po nowe tłumaczenie), aby uwydatnić sens albo odcień znaczeniowy, na który Beda zwraca szczególną uwagę.

${ }^{19}$ Vergilius, Aeneis VI 19. 
„Ten trop tworzy się w odniesieniu do Boga na różne sposoby - od ptaków, na przykład «chroń mnie w cieniu Twych skrzydeł» (Ps 17, 8); od dzikich zwierząt: «Pan zaryczy z Syjonu» (Am 1, 2); od członków ludzkich: «kto zmierzył swą garścią wody morskie i piędzią zważył niebiosa?» (Iz 40, 12); od wnętrza człowieka: «znalazłem Dawida, syna Jessego, męża według mego serca» (Dz 13, 22); od poruszeń ludzkiego umysłu: «wtedy będzie mówił do nich w swoim gniewie» (Ps 2, 5), «żałował, że stworzył człowieka» (Rdz 6, 5), «umiłowałem Syjon wielką miłością» $(\mathrm{Za} \mathrm{1,14)}$ i niezliczone przykłady tego rodzaju; od rzeczy pozbawionych zmysłów, na przykład «oto ja zmiażdżę was tak, jak miażdży walec wozowy napełniony snopami» (Am 2, 13). Ten trop jest z pewnością najczęściej używany w zwykłej wypowiedzi, na przykład wtedy, gdy mówimy «falują zasiewy», «pędy winnej latorośli okrywają się klejnotami», «kwitnąca młodość» i «mlecznobiałe włosy»"20.

Wymieniając tak wiele różnych i niepodobnych do siebie rzeczy, które mogą dać początek wyrażeniom metaforycznym odnoszącym się do Boga, Beda tworzy poręczne kategorie pozwalające porządkować biblijne metafory. Ich interpretacja uzależniona jest bowiem często od rozpoznania kierunku konstytutywnego dla nich przesunięcia znaczeniowego. Wszystkie te wspomniane rzeczy, zarówno ożywione, jak i nieożywione, związane z człowiekiem, jak i z nim niezwiązane, podkreślają sygnalizowaną już wcześniej przez Arystotelesa, Cycerona i Kwintyliana wszechobecność metafory. Nic więc dziwnego, że słów określających stworzenia używa się również w figuratywnym (obrazowym) mówieniu o Stwórcy.

Z podobnym mechanizmem retorycznym (przeniesienie znaczenia) mamy do czynienia w przypadku katachrezy, uznawanej za rodzaj nadużycia (abusio) semantycznego. Ma ona miejsce wtedy, gdy używa się danego słowa w celu oznaczenia rzeczy, której brakuje nazwy, np. ojcobójca (parricida) w odniesieniu do zabójcy brata albo staw [dosł. rybny] (piscina) dla określenia sadzawki bez ryb (pisces) ${ }^{21}$. Brak nazwy jest tym, co pozwala odróżnić katachrezę od metafory, jak w znanym fragmencie Ewangelii Janowej: ,w Jerozolimie zaś znajduje się sadzawka Owcza" (J 5, 2). Ta sadzawka (zwana również

${ }^{20}$ Beda, De schematibus et tropis, B-Bv: „Hic tropus et ad Deum fit multivarie: a volucribus, ut: «Sub umbra alarum tuarum protege me». A feris, ut: «Dominus de Sion rugiet». A membris humanis, ut: «Quis mensus est pugillo aquas et caelos palmo ponderavit?». Ab homine interiore, ut: «Inveni David filium Iesse, virum secundum cor meum». A motibus mentis humanae, ut: «Tunc loquetur ad eos in ira sua». Et: «Poenitet me hominem fecisse». Et: «Zelatus sum Sion zelo magno» et innumera huiusmodi. A rebus insensibilibus, ut: «Ecce ego stridebo super vos, sicut stridet plaustrum onustum faeno». Qui videlicet tropus et in communi locutione usitatissimus est, ut cum dicimus fluctuare segetes, gemmare vites, floridam iuventutem et lacteam caniciem".

${ }^{21}$ Sadzawka (piscina) jako przykład katachrezy pojawia się również u św. Augustyna (De doctrina christiana III 29, 40, PL 34, 80-81: „Quis non dicit piscinam etiam quae non habet pisces nec facta est propter pisces? Et tamen a piscibus nomen accepit, qui tropus catachresis dicitur", thum. Sulowski, s. 157: „Kto nie posługuje się słowem piscina (sadzawka), choć nie ma w niej ryb ani nie dla ryb została zbudowana? A jednak od ryb (pisces) wzięła swą nazwę i trop ten zwie się katachrezą"). 
Betesda), tłumaczy Beda, nie wzięła swej nazwy od ryb, ale od zwierząt ofiarnych, które obmywano w niej tuż przed złożeniem w świątyni ${ }^{22}$. Katachreza okazuje się zatem semantyczną uzurpacją (usurpatio), rodzajem nadużycia znaczeniowego, któremu udziela się tymczasowego przyzwolenia na mocy licencji retorycznej.

Metalepsa jest „wyrażeniem przechodzącym stopniowo do tego, na co ono wskazuje i wyjaśniającym za pomocą tego, co poprzedza coś, co po tym następuje”, jak np. we frazie psalmicznej: „z pracy rąk swoich będziesz pożywał” (Ps 127, 2), w której trudami (labores) określono dobra zdobywane dzięki ludzkiej pracy. Podobnie w stwierdzeniu ,ten smok, którego stworzyłeś, aby w nim [morzu] igrał" (Ps 103, 26) ${ }^{23}$ - smok oznacza tu szatana, a ten z kolei - dobrego anioła, gdyż takim stworzył go Bóg. W przypadku metalepsy przeniesienie znaczenia odbywa się stopniowo (per gradus), aby można było odtworzyć w myśli poszczególne przejścia między słowami i rzeczami. Interpretacja tego tropu, podobnie zresztą jak i innych figur opartych na translacji semantycznej ${ }^{24}$, obejmuje zatem rekonstrukcję brakujących, pozostawionych w domyśle odbiorcy, ogniw łańcucha znaczeń.

Podczas tworzenia metonimii, czyli przemianowania (transnominatio), przesunięcie znaczeniowe zachodzi w obrębie znaczeń powiązanych ze sobą relacją podobieństwa (proximitas). Może ono przybierać w dodatku rozmaite realizacje językowe: rzecz zawierająca coś zamiast zawartości (albo odwrotnie), wynalazek zamiast wynalazcy (albo odwrotnie), skutek zamiast przyczyny (albo odwrotnie), np. „teatry klaszczą” (klaszczą zgromadzeni na widowni ludzie), „łakki ryczą” (ryczą pasące się na nich krowy), „najbliższy już płonie Ukalegon”25 (płonie dom Ukalegona), ,bez Cerery i Bachusa marznie Wenus" ${ }^{26}$ (Cerera - pożywienie, Bachus - wino, Wenus - miłość; wyrażenie przysłowiowe: aby trwać, miłość potrzebuje jedzenia i napoju), „blady strach” (bladzi ze strachu ludzie). Podobnie utworzono metonimie biblijne, jak np.

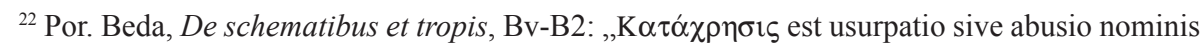
alieni aut verbi ad significandam rem, quae propria appellatione defecit et eo a metaphora differt, quod illa vocabulum habenti largitur, haec, quia non habet proprium, alieno utitur, ut paricidam dicimus, qui occiderit fratrem et piscinam, quae pisces non habet. [...] Ad hunc tropum pertinet, quod scriptum est: «Est autem Hierosolymis Probatica piscina», a piscibus enim nomen accepit aqua, quae nequaquam propter pisces, sed ad lavandas, ut ferunt, hostias collecta est, unde Probaticae cognomen sortita est".

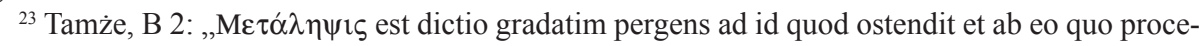
dit id quod sequitur insinuans [...]. Tale est illud: «Labores fructuum tuorum manducabis», labores enim posuit pro his quae laborando adquiruntur bonis. Nec non et illud: «Draco iste, quem formasti ad inludendum ei», per draconem diabolus, per diabolum bonus angelus intelligendus est, qualis a Deo formatus est".

${ }^{24} \mathrm{O}$ metalepsie jako odmianie metonimii typu przyczyna - skutek pisze H. Lausberg, Tropy, tłum. S. Stabryła, „Pamiętnik Literacki” 3 (1971) 211. Por. W.M. Purcell, Transsumptio. A Rhetorical Doctrine of the Thirteenth Century, „Rhetorica” 4 (1987) 369-410.

${ }^{25}$ Vergilius, Aeneis II 311-312.

${ }^{26}$ Terentius, Eunuchus V 4, 732. 
„wylewając dzban do koryta” (Rdz 24, 20) - dzban (hydria) w znaczeniu zawierającej się w nim wody, którą Rebeka napełniła koryto; „weź swe pismo” (Łk 16,7) - pismo (litterae) oznacza w przypowieści o rządcy spisane na karcie zobowiązanie dłużnika; ,wyprawcie ją w drogę, zwróćcie jednak na to uwage [...]" (1Sm 6, 8-9) - mowa w tym fragmencie nie o Arce Przymierza, ale o wozie albo wołach użytych do jej przewożenia ${ }^{27}$. Metonimia umożliwia zagęszczenie znaczeń na mocy mniej lub bardziej określonej relacji podobieństwa zachodzącej między oznaczanymi rzeczami.

Antonomazja jest słowem bądź wyrażeniem (significatio) zastępującym nazwę własną, wskazującym zazwyczaj cechy szczególne danej postaci. Tworzy sią ją na podstawie przymiotów duszy (,wielkoduszny syn Anchizesa”28, czyli Eneasz), właściwości ciała (,sam olbrzym wysoki sięga gwiazd"29 o Cyklopie) albo rzeczy zewnętrznej (,nieszczęsny młodzieniec i nierówny w walce z Achillesem”30, czyli Troilus). Analogicznie w księgach Pisma: „czyżeś nie ty powaliło wyniosłego?” (Iz 51,9) - mowa o ramieniu Pańskim; „był wysoki na sześć łokci i jedną piędź” (1Sm 17,4) - charakterystyka Goliata. Antonomazję na podstawie rzeczy zewnętrznej można tworzyć na kilka sposobów, np. za pomocą odwołania do rodzaju: „czyż syn Jessego da wam wszystkim pola?" (1Sm 22, 7) - mowa o Dawidzie, synu Jessego z pokolenia Judy; do miejsca: ,ten człowiek jest przywódcą sekty nazarejczyków” (Dz 24, 5) - zarzut skierowany przeciw św. Pawłowi jako nauczycielowi chrześcijan; do działania: „ten zaś, który go zdradził, dał im znak, mówiąc [...]” (Mt 26, 48) - pocałunek Judasza, którym wydał Mistrza oprawcom; do zdarzenia: „ów uczeń, którego Chrystus miłował" (J 21, 7) - św. Jan Ewangelista o sobie samym. Antonomazją z czegoś zewnętrznego określa się często również Boga - z rodzaju: „Hosanna Synowi Dawida!” (Mt 21, 9), z miejsca: „Ty, który zasiadasz nad cherubami” (Ps 80, 2), z działania: „zgrzeszyłem, cóż mam ci uczynić, o stróżu ludzki?" (Hi 7, 20) ${ }^{31}$.

${ }^{27}$ Por. Beda, De schematibus et tropis, B3: „His similia sunt illa de sacra Scriptura per id quod continet, id quod continetur ostendit, ut «Effundens hydriam in canalibus». Aut contra, ut: «Accipe litteras tuas», neque enim hydria effundebatur, sed quod in ea continebatur, nec litterae in manus, sed charta quae litteras continet adsumitur. Et iterum: «Et dimittite eam et vadat et aspicietis», non enim arca, sed plaustrum qui continebatur, vel boves qui ducebant plaustrum ire poterant. Haec et per efficientem, id quod fit et e contra per hoc quod fit, efficientem designat".

${ }^{28}$ Vergilius, Aeneis V 407.

${ }^{29}$ Tamże III 619.

${ }^{30}$ Tamże I 475.

${ }^{31}$ Por. Beda, De schematibus et tropis, B3v-B4: „His simile est illud, ab animo: «Numquid non tu percussisti superbum?». A corpore, ut: «Vir spurius altitudinis sex cubitorum et palmo». Ab elatione enim animi diabolus hic intelligitur superbus. A quantitate corporis Goliat gigas significatur. Extrinsecus quae sumuntur in plures species dividuntur. Descendunt enim a genere, ut: «Numquid omnibus vobis dabit filius Isai agrum?». A loco, ut: «Autorem seditionis sectae Nazaraeorum». Ab actu: «Qui autem tradidit eum, dedit eis signum dicens [...]». Ab eventu, ut: «Discipulus ille, quem diligebat Iesus». Per hunc tropum aliquoties et Dominus ipse demonstratur. A genere, ut: «Osannna 
Podobnie działa epitet, „wyrażenie przydane nazwie właściwej”. O ile jednak antonomazja zastępuje daną nazwę, o tyle epitet nie może się nigdy bez niej pojawić. Jest pod tym względem niesamodzielny znaczeniowo, np. „umiłowany przez Boga i ludzi Mojżesz” (Syr 45, 1), „miłosierny jest Pan i bardzo łaskawy” (Ps 102, 8), „[Pan wyrwał] sprawiedliwego Lota z ucisku” $(2 \mathrm{P} 2,7)^{32}$. Epitety tworzy się podobnie jak antonomazję na podstawie duszy, ciała i rzeczy zewnętrznej. Oba tropy znajdują szczególne zastosowanie podczas ganienia kogoś, dowodzenia przedłożonej tezy albo ozdabiania czegoś. Dzięki nim można dokładniej dookreślić daną rzecz, eksponując którąś z jej właściwości. Epitet ujmowany jako trop nie jest tylko zbędnym ornamentem językowym, ale stanowi ważny element współtworzący znaczenie.

$\mathrm{Z}$ analogicznym do metonimii mechanizmem retorycznym mamy do czynienia w przypadku synekdochy, ,wyrażenia obejmującego całe pojęcie, które mniej lub bardziej ujawnia”. Dotyczy ona głównie relacji między częścią a całością. Możemy dlatego rozumieć całość na postawie części (totum a parte): „Jakub przybył do Egiptu wraz z siedemdziesięcioma dwoma duszami” (Rdz 46, 27) - mowa o ludziach tworzących rodzinę Jakuba, złożonych z ciała i duszy; „Słowo stało się ciałem” (J 1, 14) - wcielenie Syna Bożego oznaczało przyjęcie całej ludzkiej natury z wyjątkiem grzechu ${ }^{33}$; ,a było nas wszystkich dusz na okręcie dwieście siedemdziesięciu sześciu" (Dz 27, 37) - relacja św. Pawła o załodze statku miotanego morskimi falami podczas podróży powrotnej Apostoła do Rzymu. Albo można rozumieć część na podstawie całości (pars a toto): „zabrali mego Pana” (J 20, 13) - słowa zaniepokojonej Marii Magdaleny szukającej ciała Chrystusa; ,tam to więc, ze względu na żydowski dzień Przygotowania, złożono Jezusa, bo grób znajdował się w pobliżu” (J 19, 42) - ciało ukrzyżowanego Chrystusa pochowano w pobliskim ogrodzie ${ }^{34}$.

filio David!». A loco, ut: «Qui sedes super Cherubin appare». Ab actu: «Peccavi, quid faciam tibi, o custos hominum?»".

${ }^{32}$ Por. tamże, B4: „Tale est in sacra Scriptura, ut: «Dilectus Deo et hominibus Moyses» et: «Misericors et miserator Dominus» et: «Iustum Loth oppressum». Fit etiam epitheton modis tribus, ab animo, a corpore, extrinsecus. His duobus tropis aut vituperamus aliquem, vel ostendimus, vel ornamus".

${ }^{33}$ Por. interesujący komentarz J. Borghesa (Dziewięć esejów dantejskich, thum. J. Partyka, Warszawa 2007, 47), który rozumiał tę synekdochę zupełnie inaczej: „Beda szukał w Piśmie Świętym przykładów figur retorycznych. I tak dla synekdochy, w której bierze się część w miejsce całości, znalazł przykład w wersecie 14 pierwszego rozdziału Ewangelii według św. Jana: «A Słowo stało się ciałem». W istocie, Słowo stało się nie tylko ciałem, lecz także kośćmi, chrząstkami, wodą i krwią”. Dla Borghesa, odwrotnie niż u Bedy, całością jest tu ciało oznaczające swe poszczególne części. Tymczasem dla angielskiego prezbitera ciało oznacza, na zasadzie synekdochy totum pro parte, ludzką naturę.

${ }^{34}$ Por. Beda, De schematibus et tropis, B4-B4v: ,Similiter in sacra Scriptura aut totum a parte ostenditur, ut: «In LXXII animabus ingressus est Iacob Aegypto», cum non solae animae, sed cum corporibus suis ingressae sunt. Aut contra, ut: «Tulerunt Dominum meum», Dominum dixit, cum Domini corpus quaereret. Aut enim totum a parte ostendit, ut: «Verbum caro factum est». Et: «Eramus vero in nave universae animae ducente septuaginta sex». Aut contra, ut ibi: «Ergo propter parasceven Iudaeorum, quia iuxta erat, monumentum ubi posuerunt Iesum»". 
Onomatopeja, czyli wyraz dźwiękonaśladowczy, jest „,nazwą utworzoną na podstawie dźwięku (nomen de sono factum)". Występuje ona również na kartach Pisma, np. „cymbał brzmiący” (1Kor 13, 1) pojawiający się u św. Pawła jako odpowiednik osoby pozbawionej miłości; „podnieś głos twój jak trąba" (Iz 58, 1) w wezwaniu do prawdziwego i miłego Bogu postu; ,dmijcie w trąby" $(\mathrm{Jr} 4,5)$ w ostrzeżeniu przed zbliżającym się z północy nieprzyjacielem; „,czyż otoczysz szyję konia rżeniem?” (Hi 39, 19); „ryk lwa” (Hi 4, 10); „wrzask lwicy” (Hi 4, 10) w plastycznych obrazach z opowieści o udręczonym Hiobie; „nieme psy niezdolne do szczekania” (Iz 56, 10) w opisie niegodnych pasterzy $^{35}$. W biblijnych księgach można odnaleźć ponadto wzmianki o syczeniu węży, chrząkaniu wieprzów i zmieszanych odgłosach innych zwierząt.

Peryfrazę, czyli omówienie (circumlocutio), stosuje się ,z powodu ozdobienia rzeczy, która jest piękna albo zganienia tego, co szpetne". Po ten trop sięgnął św. Paweł, aby wyrazić prawdę o życiu wiecznym: „Wiemy bowiem, że jeśli nawet zniszczeje nasz przybytek doczesnego zamieszkania, będziemy mieli mieszkanie od Boga, dom nie ręką uczyniony, lecz wiecznie trwały w niebie" (2Kor 5,1$)$, a w innym miejscu, aby napiętnować niegodziwość: „kobiety ich przemieniły bowiem pożycie zgodne z naturą na przeciwne naturze" $(\mathrm{Rz} 1,26)^{36}$. Tworzenie parafrazy polega zatem na unikaniu nazywania rzeczy wprost i wynajdywaniu nowych, często nieoczywistych i zaskakujących czytelnika określeń.

Podążając za Donatem, wylicza Beda pięć rodzajów hyperbatonu, pewnego wykroczenia (transcensio) przeciw sztywnym normom gramatycznej poprawności, ,naruszającego ustalony porządek słów (verborum ordinem turbans)": histerologia, anastrofa, parenteza, tmeza i synchysis. Pierwsza z tych figur, zwana również przez niektórych retorów hysteron - proteron, polega na zmianie porządku językowego, której towarzyszy zaburzenie logicznego następstwa zdarzeń, np. „taki otrzyma błogosławieństwo od Pana i miłosierdzie od Boga, swego Zbawcy" (Ps 23, 5) - najpierw Pan okazuje miłosierdzie nad grzesznikiem, odpuszcza mu grzechy i przewinienia, a następnie obdarza go błogosławieństwem ${ }^{37}$. Anastrofa to odwrócenie porządku słów (verborum ordo praeposterus), np. „Italii przeciw” zamiast „przeciw Italii”,

${ }^{35}$ Por. tamże, B4v: „Inveniuntur hae et in sacra Scriptura, ut: «Cymbalum tinniens». Et: «Quasi tuba exalta vocem tuam». Et: «Canite tuba». Et: «Numquid circumdabis collum equi hinnitum?». Et: «rugitus leonis». Et: «vox leaenae». Et: «Canes muti non valentes latrare». Ad hunc tropum pertinere quidam existimant sibilos serpentium, porcorum stridores caeterorumque vocem confusam animantium, quae et ipsa in Scripturis sanctis saepius reperitur".

${ }^{36}$ Por. tamże, B5: „Similiter et in sacra Scriptura. Veritatem splendide producit, ut est: «Scimus quoniam si terrestris domus nostra huius habitationis dissolvatur, quod aedificationem habemus ex Deo, domum non manufactum, aeternam in caelis». Foeditatem evitans, ut: «Nam feminae eorum immutaverunt naturalem usum in eum usum, qui est contra naturam»".

${ }^{37}$ Por. tamże, B5v „Tale est et istud: «Hic accipiet benedictionem a Domino et misericordiam a Deo, salutari suo», prius enim Dominus miserando iustificat impium et sic benedicendo coronat iustum". 
„z tej powodu rzeczy zwróciłbym się do Pana” (Hi 5, 8) zamiast „z powodu tej rzeczy"38. Parenteza ma miejsce wtedy, gdy daną myśl umieszczono między dwoma częściami podzielonej wypowiedzi (interposita ratiocinatio divisae sententiae), np. ,ten bowiem, który współdziałał z Piotrem w apostołowaniu obrzezania, współdziałał i ze mną wśród pogan i uznawszy daną mi łaskę, Jakub, Kefas i Jan podali mnie i Barnabie prawicę na znak wspólnoty" (Ga 2, 8-9) - słowa św. Pawła są wtrąceniem, dopowiedzeniem umieszczonym niejako na marginesie głównego toku wywodu ${ }^{39}$. Tmeza dotyczy z kolei podziału pojedynczego słowa (simplicis verbi sectio), rozbicia go na mniejsze części. Trudno znaleźć ją w Piśmie, jak przyznaje Beda, ale występuje w poezji chrześcijańskiej: „którego w Jero - zrodził - Zolimie potomek Dawida”40, to znaczy w Jerozolimie.

Najtrudniejszą odmianą hyperbatonu jest synchysis, wyrażenie „pomieszane w każdej części (ex omni parte confusum)", jak w znanym fragmencie psalmu sprawiającym wciąż wiele trudności interpretacyjnych: „gdybyście odpoczywali między zagrodami [trzody, będziecie jak] gołębica z posrebrzonymi skrzydłami, a grzbiet jej niczym złoto" (Ps 67, 14) ${ }^{41}$. Aby wyjaśnić znaczenie tej frazy, Beda przywołuje komentarz św. Augustyna, który rozpoczyna się od ustalenia odpowiedniego porządku słów. Interpretacja afrykańskiego biskupa ma charakter bardziej gramatyczny niż retoryczny. Koncentruje się wokół kwestii określenia adresata słów psalmisty. Czy poeta przemawia do lśniących niczym srebro skrzydeł gołębicy czy do tych, którzy odpoczywają w bliżej nieokreślonym miejscu? W pierwszym przypadku mowa o grzesznikach, którzy dostąpili łaski odpuszczenia grzechów zgodnie ze słowami Pisma „choćby wasze grzechy były jak szkarłat, jak śnieg wybieleją” (Iz 1, 18). W drugim - o powstaniu Kościoła, którego figurą jest śnieżnobiała (tu: lśniąca niczym srebro) gołębica, o czym wspomina również Oblubieniec: ,jedyna jest moja gołąbka” (Pnp 6, 8). To „wielkie dobro”, jakim jest odpoczynek między zagrodami, odnosi św. Augustyn do poszukiwania schronienia w cieniu autorytetu Starego i Nowego Testamentu. Uwzględnienie świadectw (testimonia) pochodzących z nich obu może ponadto uspokoić nawet najbardziej

${ }^{38}$ Por. tamże, B5v: „Tale est istud: «Quamobrem ego deprecabor Dominum» pro ob quam rem”.

${ }^{39}$ Por. tamże, B5v „Tale est et illud Apostoli: «Qui enim operatus est Petro in Apostolatum circumcisionis, operatus est et mihi inter gentes. Et cum cognovissent gratiam, quae mihi data est, Iacobus et Cephas et Ioannes dextras dederunt mihi et Barnabae societatis»".

${ }^{40}$ Por. tamże, B6: „Haec species licet in sacra Scriptura facile non inveniatur, tamen habetur in Christiano poeta, ut est: «Hiero - quem genuit - Solymis Davidica proles», hoc est Hierusalem”.

${ }^{41}$ Por. tamże, B6, B7-B7v: „Simile est illud in sacra Scriptura: «Si dormiatis inter medios cleros pennae columbae deargentatae et posteriora dorsi eius in specie auri». «Prius enim hic - ut Augustinus ait - quaerendus est ordo verborum, quomodo finiatur sententia, quae utique pendet, et dicitur: Si dormiatis, deinde incertum est utrum hae pennae, an, o vos pennae, ut ad ipsas pennas loqui videatur». [...] Magnum itaque est bonum dormire inter medios cleros, quos nonnulli duo Testamenta esse voluerunt, ut dormire sit inter duos medios cleros, in eorum Testamentorum auctoritate requiescere, ut quando aliquis ex his profertur et probatur, omnis intentio pacifica quiete finiatur". 
gorączkową dysputę. Okazuje się zatem, że ustalenie właściwego porządku słów prowadzi do rozwinięcia lektury alegorycznej zmierzającej do uspójnienia znaczeń tekstu.

Hiperbola jest „wyrażeniem przekraczającym wiarygodność (dictio fidem excedens)", utworzonym w celu powiększenia albo pomniejszenia czegoś, np. ,jaśniejszy od śniegu”, „wolniejszy od żółwia”. Korzystali z niej również autorzy ksiag biblijnych: „bystrzejsi od orłów, silniejsi od lwów” (2Sm 1, 23) - słowa Dawida opłakującego śmierć poległych w walce z Filistynami Saula i jego syna, Jonatana (hiperbola współtworzy tu laudację zmarłych); „będzie cię trwożył szum unoszonych wiatrem liści” (Kpł 26, 36) - o grzeszniku odrzucającym Boże nakazy i napomnienia; ,,ich twarz pociemniała bardziej niż węgiel $(\mathrm{Lm} \mathrm{4,8)}$ - o ludziach cierpiących z powodu głodu w poniżonej Jerozolimie $^{42}$. Beda podkreśla za Donatem głównie amplifikacyjny potencjał hiperboli.

3. Odmiany alegorii. Istotę alegorii stanowi poróżnienie sensu dosłownego i niedosłownego (figuratywnego). Jest ona tropem, który „oznacza coś innego niż to, co się mówi (aliud significatur quam dicitur)”, np. ,podnieście wasze oczy i popatrzcie na pola, jak bieleją na żniwo $(\mathrm{J} 4,35)^{43}$. Za pomocą obrazu dojrzałych kłosów zboża Chrystus mówi swoim uczniom o gotowości słuchaczy do przyjęcia wiary. Bielejące pola oznaczają tu wierzących, żniwa - głoszenie Ewangelii. Najczęściej używanymi odmianami alegorii są: ironia, antyfraza, zagadka, charientyzm, paremia, sarkazm i asteizm.

Ironia to trop ,wyrażający coś za pomocą przeciwieństwa (per contrarium quod conatur ostendens)”, jak np. w słowach Eliasza: ,wołajcie głośniej, bo Baal jest bogiem i może przemówi. Może jest zamyślony albo w drodze. Może śpi, więc niech się obudzi!" (1Krl 18, 27) - mówiąc o Baalu jako bogu, prorok odmawia mu prześmiewczo boskości. Jeśli siła wymowy (gravitas pronuntiationis), czyli odpowiednia intonacja, „nie wspomoże ironii, może się wydawać, że twierdzi się coś, czemu chce się zaprzeczyć"44.

Antyfrazę nazywa się ,,ironią pojedyncznego słowa (unius verbi ironia)”, gdyż opiera się na inwersji semantycznej (odwróceniu znaczeń). Mówimy bowiem zdaniem Donata o wojnie (bellum) jako o czymś bynajmniej pięknym (minime bellum), o zagajniku (lucus) jako miejscu pozbawionym światła (minime luceat) i Parkach (Parcae), trzech boginiach ludzkiego losu i przeznaczenia, jako o nieoszczędzających nikogo (minime parcant). Jawnie ironiczne znaczenie mają słowa wypowiedziane przez Chrystusa do nadchodzącego

${ }^{42}$ Por. tamże, B7v: „Tale est et istud: «Aquilis caeli velociores, leonibus fortiores». Minuendi, ut: «Terrebit te sonitus folii volantis». Et: «Nigrata super carbonem facies eorum»».

${ }^{43}$ Por. tamże: „Huic simile est illud: «Levate oculos vestros et videte regiones, quia albae sunt iam ad messem». Hoc est, intelligite, quia populi sunt iam parati ad credendum".

${ }^{44}$ Por. tamże, B8: „Hanc nisi gravitas pronuntiationis adiuverit, confiteri videbitur, quod negare contendit. Huic simile est illud, ut: «Clamate voce maiore, Deus est enim Baal et forsitan loquitur, aut in diversorio est, aut in itinere, aut dormit, ut excitetur»". 
z „wielką zgrają z mieczami i kijami” Judasza: „przyjacielu, po coś przyszedł?” (Mt 26, 50). Jaka różnica zachodzi zatem między ironią a antyfrazą? Trop ironiczny ujawnia się dzięki odpowiedniemu operowaniu głosem (zauważalna zmiana $\mathrm{w}$ intonacji), wypowiedź antyfrastyczna bierze zaś początek $\mathrm{z}$ przeciwieństwa, wpisanego przez jej autora w konkretne użycie jezzyka ${ }^{45}$.

Zagadka to „wypowiedź niejasna z powodu ukrytego podobieństwa rzeczy (obscura sententia per occultatam similitudinem rerum)”, np. „zrodziła mnie matka, a ona zrodziła się ze mnie" - mowa o wodzie, która zmienia się w lód, a następnie znów się rozpływa. Jako biblijną egzemplifikację zagadki przywołuje Beda fragmentu psalmu, który posłużył mu wcześniej do ilustracji synchysis, odmiany hyperbatonu: ,[będziecie jak] gołębica z posrebrzonymi skrzydłami, a grzbiet jej niczym złoto" (Ps 67, 14) ${ }^{46}$. W interpretacji tych enigmatycznych słów zaproponowanej przez benedyktyna widać ślady inspiracji komentarzem św. Augustyna. Psalmicza fraza oznacza bowiem słowa duchowo rozumianego Pisma, pełne boskiego światła. Jej ukryte znaczenie błyszczy jednak jeszcze wspanialszą łaską niebiańskiej mądrości. Można odnosić ją również do obecnego życia Kościoła radującego się dzięki skrzydłom cnót nadzieją przyszłego życia w niebie, cieszącego się z Panem wiekuistą światłością. Beda odczytuje zatem ukryte podobieństwo w omawianym psalmie jako uniwersalną naukę o interpretacji ksiąg biblijnych. Podstawowe reguły egzegezy zapisano w nieco enigmatyczny sposób w Piśmie.

Charientyzm pojawia się wtedy, gdy przykre stwierdzenie (dura dictus) czynimy łagodniejszym dla naszego odbiorcy za pomocą odpowiednio dobranych słów, np. gdy pytamy, czy ktoś nas nie szukał, a w odpowiedzi słyszymy „szczęście” (bona fortuna), to znaczy, że nikt nas po prostu nie szukał. Tą figurą posłużył się, zdaniem Bedy, Jakub w rozmowie z Labanem: „czyż nie za Rachelę ci służyłem? Czemu mnie zatem oszukałeś?” (Rdz 29, 25). Oszustwem nazywa on „największą niesprawiedliwość (iniuriam gravissimam)”, którą musiał znosić z niezwykłą cierpliwością ${ }^{47}$.

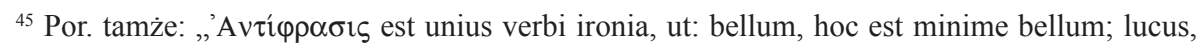
quod minime luceat; Parcae, quod minime parcant. Item in sacra Scriptura: «Amice, ad quid venisti?». Inter ironiam et antiphrasin hoc distat, quod ironia pronuntiatione sola indicat quod intelligi vult. Antiphrasis vero, non voce pronuntiantis significat contrarium, sed suis tamen verbis, quorum origo contraria".

${ }^{46}$ Por. tamże, B8-B8v: „Mater me genuit, eadem mox gignitur ex me. Cum significat aquam in glaciem coverti et ex eadem rursus effluere. Tale est illud in sacra Scriptura: «Pennae columbae deargentatae et posteriora dorsi eius in specie auri», cum significet eloquia Scripturae spiritualis divino lumine plena, sensum vero eius interiorem maiori caelestis sapientiae gratia refulgentem, vel certe vitam sanctae Ecclesiae praesentem virtutum pennis gaudentem, futuram autem, quae in caelis est, aeterna cum Domino claritate fruituram* [zam. futuram]".

${ }^{47}$ Por. tamże, B8v: ,[...] tropus quo dura dictu gratius proferuntur, ut cum interrogantibus nobis, num nos quaesierit aliquis, respondetur: «bona Fortuna». Exinde intelligitur, neminem nos quaesisse. Simile est illud: «Nonne pro Rachel servivi tibi? Quare autem imposuisti mihi?». Uno 
Paremia to przysłowie (proverbium) przystosowane do miejsca i czasu, np. „wierzgasz przeciw ościeniowi (adversus stimulum calces)"; „o wilku mowa (lupus in fabula)"; ,pies wrócił do swoich wymiocin” (2P 2, 22) - o wiernym, który odprawiwszy pokutę powrócił do swoich grzechów; „,czyż i Saul między prorokami?" (1Sm 10, 12; 19, 24) - o kimś nieuczonym, kto podejmuje się nauczania albo o kimś, kto uprawia sztukę, której się nie nauczył. Tego typu sentencjonalne stwierdzenia występują często w Piśmie. W ten właśnie sposób zapisano naukę Salomona w zbiorze pouczeń znanym jako Księga Przysłów ${ }^{48}$.

Sarkazm jest wrogim szyderstwem pełnym nienawiści (plena odio hostilisque irrisio), jak np. słowa osób naśmiewających się z ukrzyżowanego Chrystusa: ,innych wybawiał, siebie nie może wybawić. Jest królem Izraela: niechże teraz zejdzie z krzyża, a uwierzymy w Niego" (Mt 27, 42) ${ }^{49}$. Sarkazm bywa uznawany również za złośliwą ironię, obliczoną na sprawienie komuś bólu i przykrości.

I wreszcie ostatni rodzaj alegorii, czyli asteizm, który przybiera najczęściej postać błyskotliwego i wykwintnego językowo powiedzenia, przykładowo: „oby okaleczyli się sami ci, którzy was podburzają” (Ga 5, 12) - ironiczne życzenie św. Pawła pod adresem ludzi siejących zamęt wśród jego uczniów, zwłaszcza odnośnie do nauki o rzekomej konieczności obrzezania. Ten trop trudno jednoznacznie określić z powodu jego różnorodności i niezliczonych form językowych, jakie może przyjąć ${ }^{50}$.

4. Sensy Pisma. Alegorii poświęca Beda zdecydowanie najwięcej miejsca w swoim podręczniku elokucji. Jako forma retoryczna oparta na wprowadzeniu dwóch poziomów semantycznych (dosłownego i nie-dosłownego) wykraczała ona poza granice zakreślone dla tropu i ulegała przekształceniu w ogólną zasadę tworzenia (a następnie czytania) tekstu:

„Trzeba zauważyć, że alegorię tworzy się czasami za pomocą zdarzeń, a czasami za pomocą samych słów. Za pomocą zdarzeń, na przykład «napisane jest przecież, że Abraham miał dwóch synów, jednego z niewolnicy, a drugiego z wolnej» $(\mathrm{Ga} 4,22)$, którymi są, jak wyjaśnia Apostoł, dwa Testamenty. Za

enim levissimo impositionis verbo iniuriam quam patiebatur gravissimam temperantius loquens significavit".

${ }^{48}$ Por. tamże, B8v-C: „Huic simile est illud: «Canis reversus ad vomitum suum». Et: «Num et Saul inter prophetas?». Quorum unum, cum quemlibet post actam poenitentiam ad vitia relabi dicimus, altero tunc utimur, cum indoctum quemque officium docendi assumere, vel aliud quid artis, quam non didicit, sibimet usurpare viderimus. Hic tropus adeo late patet, ut liber Salomonis, quem nos secundum Hebraeos Parabolas dicimus, apud Graecos ex eo nomen Paroemiarum, hoc est Proverbiorum acceperit".

${ }^{49}$ Por. tamże, C: „Et in sacra auctoritate: «Alios salvos fecit, seipsum non potest salvum facere. Si rex Israel est, descendat nunc de cruce et credamus ei»»".

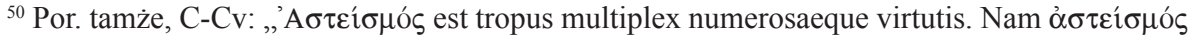
putatur, quidquid dictum simplicitate rustica caret et faceta urbanitate expolitum est. [...] Tale est et illud: «Utinam abscindantur qui vos conturbant»»" 
pomocą samych słów, na przykład «wyrośnie różdżka z pnia Jessego, wypuści się odrośl z jego korzeni» (Iz 11, 1), co oznacza, że nasz Pan i Zbawiciel miał narodzić się z Maryi Dziewicy z rodu Dawida. Niekiedy jedną i tę samą rzecz oznacza się zarówno za pomocą zdarzeń, jak i słów; za pomocą zdarzeń, na przykład «sprzedali Józefa Izmaelitom za trzydzieści sztuk srebra» (Rdz 37, 28), za pomocą zaś słów, na przykład «odważyli mi zapłatę trzydziestu srebrników» (Za 11, 12). Podobnie za pomocą zdarzeń, na przykład «Dawid zaś był rudy i piękny z wyglądu. I namaścił go Samuel pośrodku jego braci» (1Sm 16, 12-13), za pomocą słów, na przykład «mój miły śnieżnobiały i rumiany, znakomity spośród tysięcy» (Pnp 5, 10), co w obu przypadkach oznacza mistycznie Pośrednika Boga i ludzi, przyozdobionego mądrością i cnota, lecz zaczerwienionego z powodu przelania swej krwi i namaszczonego «olejem wesela przez Boga Ojca przed swoimi współuczestnikami» (Ps 44, 8)"s1.

Beda wyróżnia dwa podstawowe rodzaje mowy alegorycznej: typologię, czyli alegorię utworzoną na podstawie zdarzeń, polegającą na wpisaniu biblijnych faktów w porządek chrześcijańskiej wykładni Pisma oraz alegorię właściwa, czyli językową, opartą na generowaniu nowych, dodatkowych znaczeń $^{52}$. W pierwszym przypadku mamy do czynienia z prefiguracją - opisane w Starym Testamencie zdarzenia zostają uznane za figury znajdujące ostateczny sens w działalności Chrystusa i założonego przezeń Kościoła, w drugim - z interpretacją figuratywną zmierzającą do odsłonięcia ukrytego znaczenia. Wykorzystanie obu strategii dyskursywnych umożliwia struktura alegorii jako tropu podwójnego oznaczania, zakładającego wprowadzenie różnicy między dwoma porządkami semantycznymi, litery i figury teksty. Wypowiedź alegoryczna oscyluje bowiem wokół mówienia, jak przekonywał Kwintylian, „czegoś innego w słowie, a czegoś innego w znaczeniu (aliud verbis, aliud sensu)" "53. Lapidarny opis urody Dawida i Oblubieńca można dlatego uznać za słowa odnoszące się do Chrystusa. Co ciekawe, aby rozwinąc tę interpretację

${ }^{51}$ Tamże: „Notandum sane, quod allegoria aliquando factis, aliquando verbis tantum modo fit. Factis quidem, ut: «scriptum est, quoniam Abraham duos filios habuit, unum de ancilla et unum de libera», quae sunt duo Testamenta, ut Apostolus exponit. Verbis autem solummodo, ut: «Egredietur virga de radice Iesse et flos de radice eius ascendet», quo significatur de stirpe David per Virginem Mariam Dominum Salvatorum fuisse nasciturum. Aliquando factis simul et verbis una eademque res allegorice significatur, factis quidem, ut: «Vendiderunt Ioseph Hismaelitis triginta argenteis», verbis vero, ut: «Appenderunt mercedem meam triginta argenteis». Item factis, ut: «Erat autem David rufus et pulcher aspectu et unxit eum Samuel in medio fratrum suorum», verbis, ut: «Dilectus meus candidus et rubicundus, electus ex millibus», quod utrumque mystice significant mediatorem Dei et hominum, decorum quidem sapientia et virtute, sed sui fuisse sanguinis effusione roseum eumdemque «unctum a Deo Patre oleo laetitiae prae consortibus suis»".

${ }^{52}$ Por. A. Strubel, Allegoria in factis et allegoria in verbis, „Poétique” 23 (1975) 342-357; J. Davidse, The Sense of History in the Works of The Venerable Bede, SM 23 (1982) 647-695; A.G. Holder, Bede and the Tradition of Patristic Exegesis, ATR 72 (1990) 399-411; T.J. Furry, Allegorizing History. The Venerable Bede, Figural Exegesis, and Historical Theory, Cambridge 2014, passim.

${ }^{53}$ Quintilianus, Institutio oratoria VIII 6, 44. 
alegoryczną, angielski prezbiter sięga po kolejne frazy biblijne. Jedne figury Pisma objaśniają tym samym inne, zwielokrotniając swe możliwe znaczenia.

Ten podział alegorii uzupełnił Beda poprzez przywołanie i omówienie wyróżnionych przez Ojców Kościoła odmian sensu mistycznego Biblii:

„Podobnie alegoria słowa, czyli działania, oznacza czasami rzecz historyczną, czasami sens typologiczny, czasami tropologię, to znaczy naukę moralną, czasami anagogię, to znaczy sens prowadzący figuratywnie do rzeczy wyższych. Przez historię oznacza się figuratywnie wydarzenia, jak wtedy, gdy na podstawie pierwszych sześciu albo siedmiu dni stworzenia liczy się tyle samo epok. Przez to słowo, które mówi wtedy patriarcha Jakub: «młody lwie, Judo, mój synu, na zdobyczy rósł będziesz» (Rdz 49, 9) i tak dalej, rozumie się królestwo i zwycięstwa Dawida. Przez to słowo w sensie duchowym [rozumie się] Chrystusa, czyli Kościól, gdy tę samą wypowiedź patriarchy odnosi się wiernie do męki i zmartwychwstania Pańskiego. Podobnie alegoria zdarzeń oznacza tropologię, to znaczy doskonałość moralną, na przykład «długa szata z rękawami» (Rdz 37, 3), którą patriarcha Jakub sprawił swemu synowi Józefowi, oznacza łaskę różnych cnót, którą przyodział nas na zawsze Bóg Ojciec i której udzielił nam aż do końca naszego życia. Alegoria słowa oznacza tę samą doskonałość obyczajów, na przykład «niech wasze biodra będą przepasane i pochodnie zapalone» $(\lfloor k$ 12, 35) i tak dalej. Alegoria zdarzenia wyraża anagogię, to znaczy sens prowadzący do rzeczy wyższych, na przykład «siódmy po Adamie Henoch» (Jud 14) został zabrany ze świata, co przedstawia figuratywnie szabat przyszłej szczęśliwości, którą zachowano na końcu dla wybranych po dobrych uczynkach w tym świecie, a która nastąpi po sześciu epokach. Alegoria słowa ukazuje tę samą radość życia niebieskiego, na przykład «gdziekolwiek jest ciało, tam zlecą się i orły» (Mt 24, 28), gdyż tam, gdzie Pośrednik Boga i ludzi jest ciałem, tam z pewnością dusze wzniesione zostały od razu ku niebiosom, a ich ciała zostały ogarnięte uroczystą chwałą zmartwychwstania" ${ }^{54}$.

${ }^{54} \mathrm{Beda}$, De schematibus et tropis, C2-C2v: „Item allegoria verbi, sive operis, aliquando historicam rem, aliquando typicam, aliquando tropologicam, id est moralem rationem, aliquando anagogen, hoc est sensum ad superiora ducentem figurate* [zam. figurae] denuntiat. Per historiam namque historia figuratur, cum factura primorum sex sive septem dierum, totidem computatur aetatibus. Per verbum, dum hoc quod dicit Iacob patriarcha: «Catulus leonis Iuda ad praedam, fili mi, ascendisti» et caetera, de regno ac victoriis David intelligitur. Per verbum, spiritualis de Christo, sive Ecclesia sensus, cum idem sermo patriarchae de Dominica passione ac resurrectione fideliter accipitur. Item allegoria facta, tropologicam, hoc est moralem perfectionem designat, ut «tunica talaris et polymita» quam Iacob patriarcha filio suo Ioseph fecit, variarum virtutum gratiam, qua nos Deus Pater usque ad terminum vitae nostrae semper indui praecepit et donat, insinuat. Allegoria verbi eamdem morum perfectionem significat, ut: «Sint lumbi vestri praecincti et lucernae ardentes» et caetera. Allegoria facti, anagogicum, hoc est ad superiora ducentem sensum exprimit, ut: «Septimus ab Adam Enoch» translatus est de mundo, Sabbatum futurae beatitudinis, quae post opera bona saeculi huius, quae sex aetatibus peragitur, electis in finem servatur, figurate praesignat. Allegoria verbi eadem vitae caelestis gaudium demonstrat, ut: «Ubicunque fuerit corpus, illic congregabuntur et aquilae», quia ubi 
Cztery sensy Pisma - historyczny, alegoryczny (typologiczny), tropologiczny (zawierający pouczenia moralne dotyczące dobrego, uczciwego życia) i anagogiczny (związany z życiem wiecznym) - stanowiły stały punkt odniesienia w egzegezie patrystycznej. Pozwalały one uzgadniać ze sobą Stary i Nowy Testament i odczytywać figury biblijne w kontekście nauki chrześcijańskiej. Umożliwiały poszukiwanie jedności przekazu Objawienia w różnorodności jego form retorycznych i poetyckich. Każdy z tych sensów mógł być ponadto wyprowadzony ze zdarzenia opisanego w ,historii świętej” albo z samych słów Pisma. Wspólnym mianownikiem była dla nich uniwersalna struktura tropu alegorycznego (poróżnienie dwóch poziomów znaczeń), wykorzystywana w odpowiednim celu, np. przekazywania nauki o życiu dobrego chrześcijanina (tropologia) albo wskazywania miejsca, do którego należy zmierzać (anagogia). Dla Bedy, podobnie zresztą jak i dla wcześniejszych Ojców Kościoła, stanowiły one odmiany alegorii różniące się między sobą nie tyle mechanizmem działania, ile raczej kierunkiem przeniesienia znaczeń.

Tę prawidłowość widać szczególnie wyraźnie w przypadku zdarzeń albo słów Pisma, odczytywanych przez pryzmat wszystkich czterech sensów:

„Niekiedy jedną i tą samą rzeczą albo słowem wyraża się figuratywnie zarówno historię, jak i sens mistyczny o Chrystusie albo Kościele, tropologię i anagogię, na przykład świątynia Pana [oznacza] historycznie świątynię, którą wybudował Salomon, alegorycznie ciało Pańskie, o którym powiedział: «zburzcie tę świątynię, a w trzy dni ją odbuduję» (J 2, 19) albo Jego Kościół, któremu się powiada: «świątynia Boga jest bowiem święta, a wy niąjesteście» (1Kor 3, 17), tropologicznie kogoś z wiernych, o których się mówi: «czyż nie wiecie, że wasze ciała są świątynią Ducha Świętego, który w was przebywa?» (1Kor 3, 16); anagogicznie niebiańskie siedziby radości, do których wzdychał ten, który mówił: «szczęśliwi, którzy mieszkają w domu Twoim, Panie, nieustannie Cię wychwalają» (Ps 83, 5). W podobny sposób słowa «chwal, Jerozolimo, Pana, chwal twego Boga, Syjonie! Umocnił bowiem zawory bram twoich i pobłogosławił synom twoim w tobie» (Ps 147, 12-13) można poprawnie odnieść historycznie do ziemskiego miasta Jerozolimy, alegorycznie do Kościoła Chrystusowego, tropologicznie także do wybranej duszy, anagogicznie do niebiańskiej ojczyzny. W przypadku alegorii o Kościele, jak powiedzieliśmy, podążamy za przykładem wielce uczonego komentatora Grzegorza, który gdy objaśniał w księgach Moraliów zdarzenia i to, co powiedziano figuratywnie o Chrystusie albo Kościele, miał w zwyczaju nazywać poprawnie alegorią" 55 .

mediator Dei et hominum est corpore, ibi nimirum et nunc sublevatae ad caelos animae et celebrata gloria resurrectionis colligentur corpora iustorum".

${ }^{55}$ Tamże, C2v-C3: „Nonnunquam in una eademque re vel verbo historia simul et mysticus de Christo vel Ecclesia sensus et tropologia et anagoge figuraliter intimatur, ut: templum Domini iuxta historiam domus, quam aedificavit Salomon; iuxta allegoriam corpus Dominicum, de quo ait: «Solvite templum hoc et in tribus diebus excitabo illud», sive Ecclesia eius, cui dicitur: «Templum enim 
Beda zaznacza, że tylko niekiedy można interpretować poczwórnie fakt albo frazę wyjętą z ksiagg biblijnych. To napomnienie jest ważne szczególnie w kontekście późnośredniowiecznej praktyki kaznodziejskiej, krytykowanej i wyśmiewanej wielokrotnie przez renesansowych humanistów z Erazmem z Rotterdamu i Filipem Melanchtonem na czele. Nie brakowało bowiem wtedy kaznodziejów, którzy uczynili z czterech form alegorycznych główny wyznacznik swej sztuki głoszenia kazań. Odmieniając niemal każdy wers Pisma przez wszystkie sensy, sprowadzali sprawny model egzegetyczny do postaci karykaturalnie znieksztalconej. W rozważaniach nad działaniem i odmianami alegorii występuje Beda w podwójnej roli, a mianowicie gramatyka i retora zainteresowanego wykładem nauki o tropach i figurach, a także egzegety krótkich fragmentów biblijnych, ukazującego nieco abstrakcyjne reguły w praktyce interpretacyjnej ${ }^{56}$.

Ostatnim z omówionych przez Bedę tropów jest homoiosis, „ukazanie mniej znanej rzeczy za pomocą podobieństwa do tej rzeczy, która jest bardziej znana (minus notae rei per similitudinem eius, quae magis nota est demonstratio)". Ta figura podobieństwa występuje najczęściej w trzech odmianach: ikony, paraboli i paradygmatu. Pierwsza z nich polega na porównaniu (comparatio) osób lub związanych z nimi rzeczy z innymi osobami, np.: ,i oglądaliśmy Jego chwałę, chwałę, jaką Jednorodzony otrzymuje od Ojca" (J 1, 14) - o relacji Syna (Logosu) z przedwiecznym Ojcem; ,nie będą się ani żenić, ani za mąż wychodzić, gdyż nie będą więcej umierać, lecz będą równi aniołom” (Mt 22, 30) - o życiu ludzi po zmartwychwstaniu umarłych ${ }^{57}$.

Parabola to z kolei ,zestawienie ze sobą rzeczy niepodobnych do siebie pod względem rodzaju (rerum genere dissimilium comparatio)”, np.: „królestwo niebieskie podobne jest do ziarnka gorczycy" (Mt 13, 31); ,jak Mojżesz wywyższył węża na pustyni, tak trzeba, by wywyższono Syna Człowieczego" $(\mathrm{J} 3,14)^{58}$. Ten obrazowy sposób mówienia, polegający na przekształceniu niepodobieństwa w ukryte podobieństwo, charakteryzuje przede wszystkim mowy proroków i przypowieści Chrystusa.

Dei sanctum est, quod estis vos»; per tropologiam quisque fidelium, quibus dicitur: «An nescitis quia corpora vestra templum est Spiritus sancti, qui in vobis est?»; per anagogen superni gaudii mansiones, cui aspirabat qui ait: «Beati qui habitant in domo tua, Domine, in saeculum saeculi laudabunt te». Simili modo quod dicitur: «Lauda, Ierusalem, Dominum, lauda Deum tuum, Sion, quoniam confortavit seras portarum tuarum, benedixit filiis tuis in te», de civibus terrenae Hierusalem, de Ecclesia Christi, de anima quoque electa, de patria caelesti, iuxta historiam, iuxta allegoriam, iuxta tropologiam, iuxta anagogen, recte potest accipi. Iuxta allegoriam de Ecclesia, diximus, sequentes exemplum doctissimi tractatoris Gregorii, qui in libris Moralibus, ea quae de Christo sive Ecclesia per figuram dicta, sive facta interpretabantur, allegoriam proprie nuncupare solebat".

${ }^{56}$ Por. C. O’Brien, Bede's Temple. An Image and Its Interpretation, Oxford 2015, passim.

${ }^{57}$ Por. Beda, De schematibus et tropis, C3v: „Simile est illud in sacra Scriptura, ut: «Vidimus gloriam eius, gloriam quasi unigeniti a patre». Et: «Neque unbent, neque ducent uxores, neque enim ultra mori poterunt, aequales enim angelis erunt»".

${ }^{58}$ Por. tamże: „Simile est et illud: «Simile est regnum caelorum grano sinapis». Et: «Sicut Moyses exaltavit serpentem in deserto, ita exaltari oportet filium hominis»»". 
Retorycznie rozumiany paradygmat jest „przedłożeniem, czyli opowiedzeniem przykładu zachęcającego albo zniechęcającego do czegoś (praepositio, sive enarratio exempli hortantis aut deterrentis)", jak przykładowo w następujących zachętach: „Eliasz był człowiekiem podobnym do nas, cierpiącym, i modlił się usilnie, by deszcz nie padał, i nie padał deszcz na ziemię przez trzy lata i sześć miesięcy" $(\mathrm{Jk} 5,17)$ - wezwanie do gorliwej i wytrwałej modlitwy; ,przypatrzcie się ptakom w powietrzu: nie sieją ani żną i nie zbierają do spichrzów, a Ojciec wasz niebieski je żywi” (Mt 6, 26) - przestroga przed zbytnimi troskami; albo jako zniechęcenie: „w owym dniu kto będzie na dachu, a jego rzeczy w mieszkaniu, niech nie schodzi, by je zabrać; a kto na polu, niech również nie wraca do siebie. Przypomnijcie sobie żonę Lota" (Łk 17, 31-32 $)^{59}$. Można powiedzieć, że ta figura stanowi krótką narrację właściwą dla rodzaju doradczego (zachęta - zniechęcenie).

\section{$* * *$}

W podręczniku Bedy terminologia gramatyczno-retoryczna stała się językiem opisu sztuki objaśniania autorów biblijnych (hermeneutyki). Ze sztywnych schematów wysłowienia tropy uległy przekształceniu w sprawne narzędzia zwielokrotniania znaczeń. Alegoria awansowała dzięki temu do rangi tropu odgrywającego kluczową rolę w egzegezie tekstu (historia, typologia, tropologia i anagogia), ukazując bogactwo składających się nań sensów. Pismo było dla Bedy, podobnie jak dla niektórych Ojców-retorów, niczym figura - przesłonięte literą i wieloznaczne, obrazowe jak metafora, zwięzłe jak metonimia albo synekdocha, czasami ambiwalentne jak ironia, pojemne jak alegoria, aby mogło rzucić choćby nikły promyk światła na „rzeczy ukryte od założenia świata" (Mt 13, 35).

\section{UT FIGURA SIT: \\ THE VENERABLE BEDE ON TROPES OF THE SCRIPTURE}

(Summary)

The main purpose of the paper is to discuss thirteen tropes presented by the Venerable Bede, a Benedictine monk from the Kingdom of Northumbria, in the manual On figures and tropes (De schematibus et tropis, ca. 710), dedicated to his disciple, Cuthbert. Using the definitions and examples given by Donatus (Ars

${ }^{59}$ Por. tamże, C4: „Simile est et illud exhortantis, ut: «Elias homo erat similis nobis passibilis et orationem oravit ut non plueret super terram et non pluit annis tribus et mensibus sex» et: «Respicite volatilia caeli, quoniam non serunt, neque metunt, neque congregant in horrea et pater vester caelestis pascit illa». Deterrentis, ut: «Illa hora qui fuerit in tecto et vasa eius in domo, non descendat tollere illa; et qui in agro, similiter non redeat retro. Memores estote uxoris Loth»". 
maior), Bede described thirteen tropes and their variants: metaphor, catachresis, metalepsis, metonymy, antonomasia, epithet, synecdoche (totum a parte, pars a toto), onomatopoeia, periphrasis, hyperbaton (histerologia, anastrophe, parenthesis, tmesis, synchysis), hyperbole, allegory (irony, antiphrasis, enigma, charientism, paremia, sarcasm, asteism), and homoeosis (icon, parable, paradigm). Each of these rhetorical devices was illustrated with examples drawn from the Scripture. Therefore, the categories form the grammatical tradition were transformed into the exegetical means, particularly useful during reading the Bible and discovering its hidden meanings. Deploying tropes for interpretative purposes, Bede proposed the model of exegesis concentrated on both what is signified and the mode of signification.

Key words: the Venerable Bede, tropes, rhetorical figures, biblical exegesis.

Słowa kluczowe: Beda Czcigodny, tropy, figury retoryczne, egzegeza biblijna.

\section{BIBLIOGRAFIA}

\section{Źródła}

Augustinus, De doctrina christiana, PL 34, 15-122, tłum. J. Sulowski: Św. Augustyn, O nauce chrześcijańskiej, Warszawa 1989.

Beda Presbyter Anglosaxonis, De schematibus et tropis sacrarum litterarum liber, Basileae: apud Adamum Petrum, mense Augusto 1527.

Opracowania

Borghes J., Dziewięć esejów dantejskich, tłum. J. Partyka, Warszawa 2007.

BLAIR P.H., The World of Bede, Cambridge (MA) 1990.

Brown G.H., Bede The Venerable, Boston 1987.

BurCzAK K., Figury retoryczne i tropy w Psalmach na podstawie „Expositio Psalmorum” Kasjodora, Lublin 2004.

Copeland R., Rhetoric, Hermeneutics and Translation in the Middle Ages. Academic Traditions and Vernacular Texts, Cambridge 1991.

Davidse J., The Sense of History in the Works of The Venerable Bede, SM 23 (1982) 647-695.

DeGregorio S., The Venerable Bede and Gregory the Great: Exegetical Connections, Spiritual Departures, „Early Medieval Europe” 18 (2010) 43-60.

Elder J.P., Did Remigius of Auxerre Comment on Bede's De schematibus et tropis?, „Mediaeval Studies" 9 (1947) 141-150.

Franklin C.V., The Date of Composition of Bede's „,De schematibus et tropis” and „De arte metrica”, RBen 110 (2000) 199-203.

FurRY T.J., Allegorizing History. The Venerable Bede, Figural Exegesis, and Historical Theory, Cambridge 2014.

GREEn L.D., Grammatica movet: Renaissance Grammar Books and elocutio, w: Rhetorica movet. Studies in Historical and Modern Rhetoric in Honour of Heinrich F. Plett, ed. P.L. Oesterreich - T.O. Sloane, Leiden 1999, 73-115.

Green L.D. - Murphy J.J., Renaissance Rhetoric Short Title Catalogue: 1460-1700, Aldershot 2006. 
Holder A.G., Bede and the Tradition of Patristic Exegesis, ATR 72 (1990) 399-411.

IRVInE M., The Making of Textual Culture: ,, Grammatica” and Literary Theory 350-1100, Cambridge (MA) 1994.

KnAPPE G., Traditionen der klassischen Rhetorik im angelsächsischen England, Heidelberg 1996.

Lausberg H., Tropy, tłum. S. Stabryła, „Pamiętnik Literacki” 3 (1971) 193-216.

MichaŁowska T., Literatura polskiego średniowiecza wobec poetyki europejskiej (,, ornatus difficilis"), Warszawa 2008.

Michąowska T., Średniowieczna teoria literatury w Polsce. Rekonesans, Torun 2016.

Murphy J.J., Rhetoric in the Middle Ages. A History of Rhetorical Theory from Saint Augustine to the Renaissance, Berkeley - Los Angeles 1974.

O'BRIEN C., Bede's Temple. An Image and Its Interpretation, Oxford 2015.

Purcell W.M., Transsumptio. A Rhetorical Doctrine of the Thirteenth Century, „Rhetorica" 4 (1987) 369-410.

Ray R.L., Bede, Rhetoric, and the Creation of Christian Latin Culture, Jarrow 1997.

Reynolds S., Medieval Reading: Grammar, Rhetoric and the Classical Text, Cambridge 2004.

RyczeK W., „,De rhetorica christiana” św. Augustyna: między filologia a filozofia, w: Studia rhetorica, red. M. Choptiany - W. Ryczek, Kraków 2011, 211-225.

Schindel U., Die Quellen von Bedas Figurenlehre, CM 29 (1968) 169-186.

Strubel A., Allegoria in factis et allegoria in verbis, „Poétique” 23 (1975) 342-357.

Thacker A., Bede and Augustine of Hippo. History and Figure in Sacred Text, Jarrow 2005. 